Artículo científico

Volumen 31(3):619-633. Septiembre-diciembre, 2020

e-ISSN 2215-3608, doi:10.15517/am.v31i3.40349

http://www.revistas.ucr.ac.cr/index.php/agromeso

\title{
Improving strategic management through risk analysis: small palm (Elaeis guineensis) oil industrializers, Central America ${ }^{1}$
}

\section{Mejora de la gestión estratégica a través del análisis de riesgo: pequeños industrializadores de aceite de palma (Elaeis guineensis), América Central}

\author{
Javier Paniagua-Molina², Johanna Solórzano-Thompson ${ }^{2}$
}

1 Reception: January 15, 2020. Acceptance: May 19, 2020. This work is part of the 822-B7-518 research project registered with the Centro de Investigaciones en Economía Agrícola y Desarrollo Agroempresarial (CIEDA).

2 Universidad de Costa Rica, Escuela de Economía Agrícola y Agronegocios. San José, Costa Rica. javier.paniagua@ucr.ac.cr (https://orcid. org/0000-0003-2815-5437), johanna.solorzano@ucr.ac.cr (https://orcid.org/0000-0002-0276-6849).

\begin{abstract}
Introduction. Palm cultivation allows oil to be obtained for human and industrial consumption. Some of its development has been achieved through associations of agricultural producers, who have had access to financing to build industrial plants for oil extraction and refinement, which is of great importance to the economy developing countries. Objective. To demonstrate how strategic and risk management influence the profitability and value of the small palm oil industrializer business. Materials and methods. Financial, technical, market, and production indicators were used in a price forecast model. The Monte Carlo simulation method was performed and a time series model was fitted to forecast the international price of palm oil. Subsequently, a univariate structural econometric model was adjusted to forecast revenue based on international price and other variables. Finally, a parameterized cash flow was developed that incorporated the results of the previous models to estimate the value of the business. Results. The international oil price forecast showed high volatility that directly affected the organization's revenue forecasts and conveyed its effect to cash flows. The value of the business and equity was negative, and in the face of debt restructuring scenarios and the elimination of unproductive assets, they improved considerably. Conclusion. Low-diversified palm oil production companies had a high exposure to changes in international prices which, together with high levels of debt for fixed asset investments with long recovery periods, affect their cash flow, the value of the company, and its assets.
\end{abstract}

Keywords: risk management, risk analysis, financial modeling, econometric modeling, palm oil business.

\section{Resumen}

Introducción. El cultivo de palma permite obtener aceite para consumo humano e industrial. Parte de su desarrollo se ha logrado a través de asociaciones de productores agrícolas, quienes han tenido acceso a financiamiento para construir plantas industriales para la extracción y el refinamiento del aceite, lo que resulta de gran importancia para la economía de países en desarrollo. Objetivo. Demostrar cómo influye la gestión estratégica y de riesgos en la rentabilidad y el valor del negocio de pequeños industrializadores de aceite de palma. Materiales y métodos. Se utilizaron indicadores financieros, técnicos, de mercado y producción, en un modelo de pronóstico de precios. Se ejecutó 
el método de simulación Monte Carlo y se ajustó un modelo de serie temporal para pronosticar el precio internacional del aceite de palma. Posteriormente, se ajustó un modelo econométrico estructural univariado para pronosticar los ingresos en función del precio internacional y otras variables. Finalmente, se elaboró un flujo de caja parametrizado que incorporó los resultados de los modelos anteriores para estimar el valor del negocio. Resultados. El pronóstico del precio internacional del aceite mostró una alta volatilidad que afectó directamente los pronósticos de ingresos de la organización y transmitió su efecto a los flujos de caja. El valor del negocio y del patrimonio se presentaron negativos, y ante escenarios de reestructuración de deuda y de eliminación de activos improductivos, se mejoraron considerablemente. Conclusión. Las empresas de producción de aceite de palma poco diversificadas tuvieron una alta exposición a los cambios en el precio internacional que, aunado a altos niveles de deuda para inversiones en activos fijos con amplios periodos de recuperación, afectan su flujo de caja, el valor de la empresa y su patrimonio.

Palabras clave: gestión de riesgo, análisis de riesgo, modelación financiera, modelación econométrica, negocio de aceite de palma.

\section{Introduction}

The palm sector had great importance for the rural economy in developing countries of the American tropical belt. Oil palm (Elaeis guineensis) adapted very well to tropical conditions and allowed obtaining oil, both for human consumption and for the production of biofuels as an alternative to fossil fuels. Much of the development of this crop in these areas, had been carried out through associations of small and medium-sized agricultural producers, who, in this way, also had access to financing to build the industrial plants needed for the extraction and refining of palm oil.

Before 2018, oil palm was one of the crops with the greatest expansion worldwide with an annual average growth of $5 \%$ in the cultivated area, which allowed it to exceed 69,774 million tons of palm oil in 2017, and Indonesia, Malaysia and Thailand were the main producers with approximately $88 \%$ of total world production (Ordoñez and Valencia, 2018). On the other hand, Costa Rica ranked $14^{\text {th }}$ among 28 palm oil producing countries in 2017, reporting 270,000 t (0,39\% of world production), and four Latin American countries (Colombia, Guatemala, Ecuador and Honduras) were among the eight main producers, covering $5 \%$ (3,506 million MT) of total production (Ordoñez and Valencia, 2018).

In 2017, 49,891 million MT was commercialized and the largest marketers palm oil worldwide were Indonesia (58\%), Malaysia (29\%), Thailand (4\%) and Colombia (2\%). Indonesia and Malaysia accounted for $90.80 \%$ of the exports made, while in Latin America approximately $4.30 \%$ of the world total was report, including in addition to Guatemala and Colombia, other countries such as Honduras, Ecuador and Costa Rica (Ordoñez and Valencia, 2018). Regarding the main buyers of palm oil for the year 2017, India was the first with $23.54 \%$ of the total, followed by European Union with 14.43\% and China with 10.66 \% (González-Cárdenas, 2017).

Due to the increase of the population and the demand for food, by the year 2050 an additional 150 million tons of vegetable oils and fats were projected, this would imply an increase of 36 million hectares if it were the specific case of supplying these quantities with African palm oil (González-Cárdenas, 2017).

The palm sector had suffered serious damage worldwide, due to the international price of oil and the attack of diseases, including the so-called dry arrow (Chinchilla, 2008; Correa, 2015). The dry arrow or bud rot is a disorder that affects the development, physiology and yield of the oil palm (Chinchilla, 2008). The initial symptoms in the foliage usually manifest with the chlorosis of a few leaflets located at the base of some of the recently opened leaves especially at the base of the head; in addition, problems were observed in the root system of the plant (Chinchilla, 2008).

The disease was reported in the sixties in Colombia and Panama; in 1982 caused severe losses in Surinam, and 
in Brazil it was reported in the year 1985. The presence in the Southern Costa Rica was reported in 1994, onwards it was observed in the Central Pacific (Meza, 2012). This disease has destroyed a great area of plantations in Panama, Colombia, Surinam, Brazil and Ecuador, generating losses in productivity of up to $50 \%$.

The risk analysis is useful in agribusiness to simulate some multiple scenarios under many changes and variables.

Simulation is typically a process that attempted to imitate how events might take place in real life. At the most basic level, the random element in a financial simulation model was a random variable, which is a quantification that can change. How a random variable was first established and how it changed each time it is very critical and it was necessary to keep in mind that proper terminology for random numbers that have deterministic attributes was pseudorandom numbers (Allman et al., 2011).

A probabilistic simulation based on the Monte Carlo method, submits a mathematical model to several series of simulations or runs and it was useful to estimate the probability of an investment cost over a certain level, and it had been use by several authors contributing with business applications (Savvides, 1994; Simões and Scherrer, 2014; Botond and Bela-Gergely, 2016).

The Monte Carlo simulation method used mainly on estimating the probability distributions for each of the variables or unknown components, including the life of the project only if this was uncertain, generating random numbers that allow calculating the components individually and determined the impact of each of them on the project (Bonini, 1975). The Monte Carlo simulation method (MCS) is one of the most used in the risk analysis of investment projects, where it involves defining the variables that affect the cash flow with probability distributions for each of them, which allows a joined of variability in multiple scenarios (Hojjati and Noudehi, 2015; Janeková, 2015).

This method was implemented in furniture manufacturing of wood with the objective to identify critical factor that affect the expected profit and cash flow in the execution of investment projects (Merková et al., 2013). The results of the sensitivity analysis of the project by changing the values of the project by $\pm 10 \%$, show that the main risk factors that cause the decrease in profit were the sale price, the volume of production, the cost of materials and the labor costs. This allowed the decision to mitigate the risk of investment through diversification, offering the possibility of expanding the range of products available to the final consumer.

In the context of investment projects, risk is defined as the possibility of financial loss, which generates uncertainty to achieve the desired results and variability of the returns associated with the investment (Junkes et al., 2015). A risk event affect a investment project even in a good or bad way with an estimated probability, while under uncertainty there is not enough information to determine the probability of occurrence of the event. Risk analysis facilitates decision-making and reduces uncertainty; however, it is one of the most underestimated parts of a project (Merková and Drábek, 2015).

It is essential to use as much data as possible to carry out a risk analysis, which allows describing quantitatively the variables that generate uncertainty in the project, as a point estimated of the central tendency of the risk exposure does not indicate the uncertainty of the estimated. Similarly, a point estimated of high quality can be much higher than the central tendency (Poulter, 1998).

Risk management activities using derivatives and commodity price-indexed debt, with regard to commodity price risk, have been documented in several businesses (Bilson, 1994; Tufano, 1996; Chidambaran et al., 2001; Petersen and Thiagarajan, 2000; Haushalter, 2000; Bartram, 2005). However, the need has been pointed out for the private sector, with businesses exposed to the influence of commodity price volatility, to make use of the wide range of market risk hedges and derivatives for markets of futures, options, swaps, commodity bonds and debt instruments (Varangis and Larson, 1996). If farmers do not have direct access to these instruments, intermediaries should be developed for this.

A comprehensive investigation of non-financial firms with exposure to the price of a variety of commodities, it showed that the percentage of firms with significant commodity price exposure was generally above the $5 \%$ significance level (Bartram, 2005). Despite this, Bartram (2005) points out that his findings on the impact of 
commodity price risk are relatively unimportant for many corporations due to the small effect in relation to the size of total cash flows for many corporations.

In the case studied, the effect is very strong because the organization is dedicated exclusively to palm oil processing. If commodity price fluctuations represent an important source of risk, nonfinancial firms must routinely reduce their exposure through hedging, for instance by using derivatives or commodity price-linked debt.

This work was carried out from a case study of a small palm oil processing industry in Central America, which only sells crude oil on the international market. The objective of this paper was demonstrate how strategic and risk management influences the profitability and value of the small palm oil industrializer business.

\section{Materials and methods}

This research was carried out with small-size palm oil industrializers represented by a rural organization, whose identity is not revealed at their request. This organization works in the Latin American in tropical belt and has been operating for thirty-years ago.

For sales modeling, a structural univariate econometric model was fitted with sales as dependent variable that is a function of the international crude palm oil price, one period lagged sales and a binary condition of a disease risk presence capture by means a dummy variable. The formal definition is the following (1):

$$
S_{t}=\hat{\beta}_{0}+\hat{\beta}_{1} P_{t}+\hat{\beta}_{2} S_{t-1}+\hat{\beta}_{3} D_{t}+\hat{u}_{t}
$$

Where,

$S_{t}=$ natural logarithmic of sales in each $t$ year (local currency);

$P_{t}=$ natural logarithmic of world crude palm oil price in US\$/metric ton in each $\mathrm{t}$ year;

$D_{\mathrm{t}}=$ a dummy variable where " 1 " is the presence of the dried arrow disease and 0 is the absence of it;

$S_{t-1}=$ sales lagged one-year (local currency).

The sales projection was one of the most critical elements in a financial model because it was central to determine the value of the company in parametric model. Among others, a way to forecasting sales was building an econometric model that relates the sales with key explicative variables such as, political scenarios, interest rate, grow rates, prices, costs, inflation rate and lagged sales (Allman et al., 2011; Benninga, 2014). To obtain the forecast of future palm oil prices and use them like a repressor "P" in the structural econometric model presented above, an ARIMA model adjusted to the time series of the international palm oil price was used since 1961 to 2017 , with Box-Jenkins methodology (Box et al., 2016) . $^{3}$

A financial model is a quantitative representation of a company's past, present, and future business operations. These models, use the balance sheet, the income statement and the cash flows statement as a basis (Proctor, 2010). In addition, it is necessary to choose the ratios that show consistency preferring instead to use our judgment, but context information must also be incorporated (Benninga, 2014).

In model of random behavior of ratios, a set of several probability distribution was applied to fit the data, like following: Generalized Extreme Value (GEV) distribution, extreme value distributions, the uniform distribution, Laplace distributions, Pareto distribution, and the normal distribution.

The uniform distribution represents the case in which a random variable can only take values between two extremes a and $b$, so that all intervals of the same length within $[a, b]$ have the same probability; or it can be a probabilistic model that takes a random number within an interval [a, b] (Baddi and Castillo, 2009).

3 Data available at World Bank as ISTA Mielke GmbH, Oil World, Palm oil (Malaysia), 5 \% bulk, c.i.f. N. W. Europe. 
Laplace distribution is known as an alternative to the normal distribution for measuring the errors of the mean, with the difference that Laplace is expressed in terms of the absolute difference $|x-\mu|$ and the normal in terms of squared difference $(x-\mu)^{\wedge} 2$ (Espejo-Miranda et al., 2006).

The normal distribution, known as the Gauss bell due to its graphic representation, turns out to be the most important of the statistical distributions due to the number of phenomena it explains. In this distribution function, the average, the median and the fashion are located in the center of the curve. It is symmetric around its average, it is asymptotic because its ends tend to infinity and never touch the horizontal axis, the total area under the curve represents $100 \%$, and the central elements of the model are the mean and the variance (Quevedo, 2011).

Net Present Value (NPV), it allows calculating the present value of a certain number of future cash flows, coming from a business or investment. In other words, the NPV gives the present value of cash flows discount through a rate.

The current time all future cash or cash flows in a given evaluation period; once these values are updated and a summation of them is made, the initial investment must be subtracted with the objective of visualizing the effect of the economic benefit generated by the business (Sapag and Sapag, 2008). The present net value is calculated with the following equation (2):

$$
V A N=\sum_{t=1}^{n} \frac{B N_{t}}{(1+i)^{\mathrm{t}}}-I_{0}
$$

Where,

$B N_{t}$ : represents the net benefit of the flow in the $t$ period;

$i$ : is the discount rate;

$I_{0}$ : is the initial investment at time zero of the evaluation.

The business value of a company may be find by a flow discount method for a very long time (Fernández, 2001) and it can write as follows (3):

$$
V=\frac{C F_{1}}{1+k}+\frac{C F_{2}}{(1+k)^{2}}+\frac{C F_{3}}{(1+k)^{3}}+\ldots+\frac{C F_{n}+V R_{n}}{(1+k)^{\mathrm{n}}}
$$

Where,

$C F_{n}$ : is the flow of funds generated by the company in time $\mathrm{i}$;

$V R_{n}$ : is the residual value of the company in year $\mathrm{n}$;

$k$ : is the discount rate for the risk of cash flows.

The cost of foreign currency capital (in this case is United States dollars) at the local level, is determined based on the capital asset price model (CAPM) adjusted for the country risk as equation 4 :

$$
W A A C(U S D)=k_{f}+\beta\left(k_{m}-k_{f}\right)+C_{r}
$$

Where,

$W A A C(U S D)=$ cost of capital of the partners in external currency;

$k_{f}=$ free risk annual rate;

$k_{m}=$ market risk return rate measured by a complex stocks index like SP500; 
$\beta=$ systematic market risk measure unlevered in first step and levered by debt ratio in second step;

$C_{r}=$ country risk.

The cost of capital of the partners in local currency at the local level is determined based on the capital asset price model (CAPM) adjusted for the previous country risk, but also adjusted for the relative inflation between the country of the currency of reference and the country where the project is developed (equation 5):

$$
W A A C(\text { local currency })=[1+W A A C(U S D)]\left[\frac{1+\pi_{L}}{1+\pi_{I}}\right]-1
$$

Where,

$\pi_{L}=$ inflation rate for local country;

$\pi_{I}=$ inflation rate for external currency.

Finally, the following formula (6) represents the average capital cost for the several financing sources:

$$
k_{a}=W_{d} k_{d}(1-t)+W_{s} k_{s}
$$

Where,

$k_{a}=$ average annual capital cost;

$k_{d}=$ debt annual interest rate;

$W_{d}=$ weight for debt;

$W_{s}=$ weight for stocks;

$t=$ tax rate.

To consider an indefinite duration of the flows from year $n$, a constant growth rate $(\mathrm{g})$ of the flows must be assumed and the residual value obtained in year $n$ as follows (7), considering that $k>0$ :

$$
V R_{n}=C F_{n} \frac{(1+g)}{(k-g)}
$$

Finally, the equity value can be obtained by subtracting the level of debt to business value and represents a net business value available to stockholders, after pay to debt creditors.

For risk analysis, two simulation alternatives are defined as case 1 and case 2, where in the first one, interest rate used for the debt is $10,49 \%$, which is the current average rate of all the debts of the company; and in the second one, the interest rate is defined on $6 \%$. This last fact in based faced with a real possibility of adapting long-term debt, it is feasible to think of a scenario where a financial restructuring is presented in such a way that the interest rate is lowered to that level.

For the purposes of evaluating the relative quality of the statistical models fitted for a data set, the Akaike Information Criterion (AIC) (8) proposed by Akaike (1974) was used. Based on these criteria, for two comparable econometric models, the model with the lowest AIC is selected because it has a better forecast fit (equation 8).

$$
A I C=2 k-2 \ln (L)
$$


Where,

$\mathrm{k}=$ number of parameters of statistical model;

$\mathrm{L}=$ is the maximum value of the likelihood function for the estimated model.

\section{Results}

The international price forecast for palm oil is presented in Figure 1. The results show broad confidence intervals for estimating the average (price per metric ton) for each year, which can be translated into a representation of volatility.

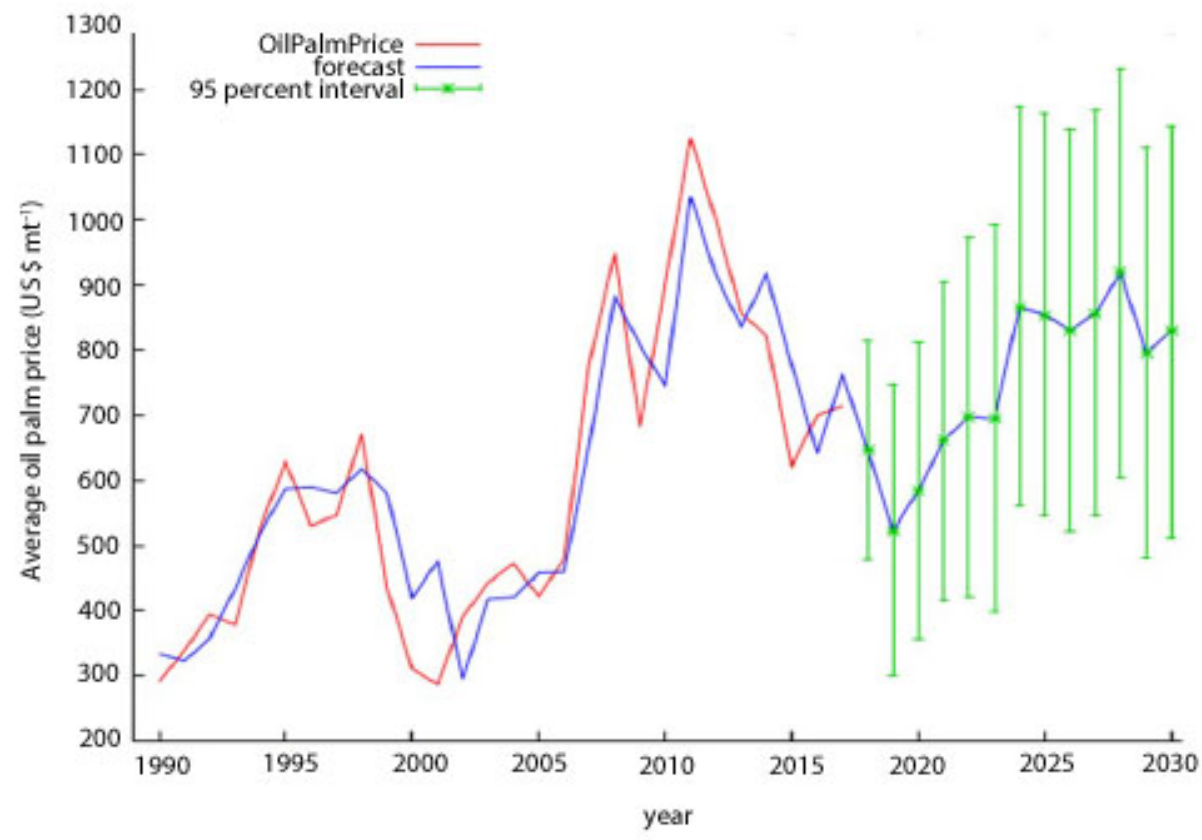

Figure 1. International palm (Elaeis guineensis) crude oil price forecast. Central America. 2017.

Source: Authors, with data from ISTA Mielke GmbH (2017).

Figura 1. Pronóstico del precio internacional del aceite crudo de palma (Elaeis guineensis). América Central. 2017.

Fuente: Autores, con datos de ISTA Mielke GmbH (2017).

The historical sales behavior in front of the dynamics of international palm oil price and the level of asset and debts value according to the financial statements are shown in Figure 2. The main fact was the strategic investments and indebtedness were not being in concordance with the international price movement. In other words, there had a positive correlation between the international price and sales, and the organization took the decision to invest and borrow despite the imminent and sustained fall in the international price. Another factor that contributes to the sales fall was the presence of dried arrow disease condition in the region that was especially strong during 2013, 2014 , and 2015. 


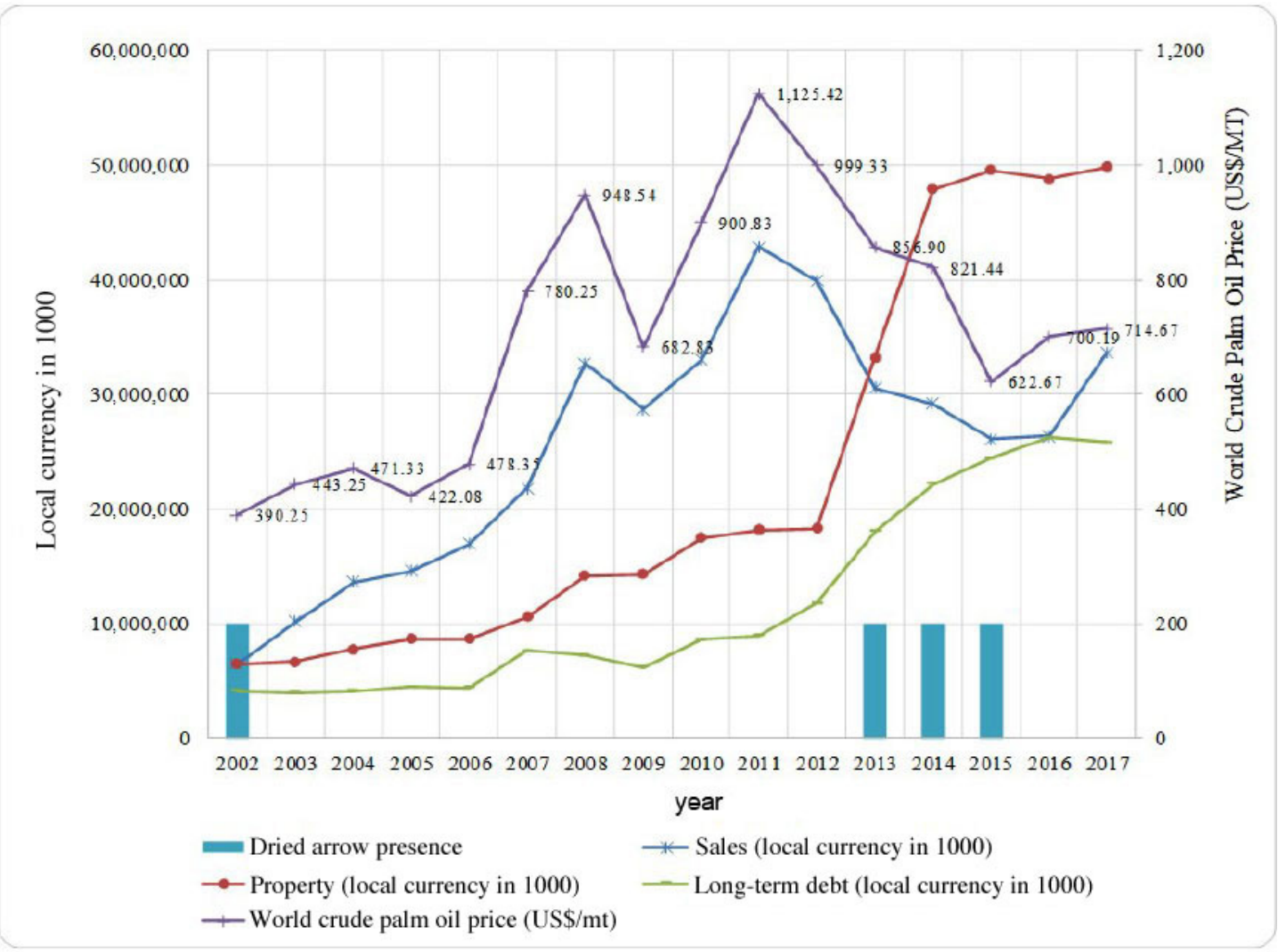

Figure 2. Response of strategic investment and debts in front of palm (Elaeis guineensis) oil sales fall-down, small-industrializer case. Central America. 2017.

Source: Authors, with data from ISTA Mielke GmbH (2017).

Figura 2. Respuesta de las inversiones estratégicas y deudas frente a la caída de las ventas de aceite de palma (Elaeis guineensis), el caso de un pequeño industrializador. América Central. 2017.

Fuente: Autores, con datos de ISTA Mielke GmbH (2017).

The results of Ordinary Least Squares (OLS) for a structural univariate model where the sales in the $t$ time was explained by the international palm oil price, the sales lagged one-year and the presence of the dried Arrow condition measured by a binary dummy variable, are shown in Table 1.

In the Lagrange Multiplicator (LM) test for autocorrelation up to order 1, where the null hypothesis was the no autocorrelation condition, the test statistic $\mathrm{LM}$ was 2.44241 with $\mathrm{p}$-value $=\mathrm{P}(\mathrm{F}(1,10)>2.44241)=0.149159$. There is no statistical evidence to reject the null hypothesis, and it was possible to maintain the absence of the correlation in residuals.

The Breusch-Pagan test for heteroscedasticity with test statistic: $\mathrm{LM}=1.34529$, with $\mathrm{p}$-value $=\mathrm{P}(\mathrm{Chi}$-square(3) $>1.34529)=0.718408$, indicates that there was not an heteroscedasticity condition in the residuals.

The forecast efficacy was good with a mean error of $-1.1842 \mathrm{e}-015$, root of mean squared error 0,073086 , and Theil's U 0.36135 . 
Table 1. Ordinary least squares (OLS) results for univariate econometric modeling of palm (Elaeis guineensis) oil sales in local currency, small-industrializer case. Central America. 2017.

Cuadro 1. Resultados de mínimos cuadrados ordinarios (OLS) para el modelo econométrico univariado de ventas de aceite de palma (Elaeis guineensis) en moneda local, el caso de un pequeño industrializador. América Central. 2017.

\begin{tabular}{|c|c|c|c|c|c|}
\hline Variable & Coefficient & Std. Error & t-ratio & p-value & $\begin{array}{c}\text { Statistical } \\
\text { significance }^{1}\end{array}$ \\
\hline const & 8.319 & 130.658 & 6.367 & $<0.0001$ & $* * *$ \\
\hline Crude oil palm price $_{\mathrm{t}}$ & 0.588349 & 0.126804 & 4.640 & 0.0007 & $* * *$ \\
\hline Dried $_{\text {arrow }}$ & -0.126383 & 0.0625045 & -2.022 & 0.0682 & $*$ \\
\hline Sales $_{t-1}$ & 0.49468 & 0.0795977 & 6.215 & $<0.0001$ & $* * *$ \\
\hline Mean dependent var & $2,393,380$ & & S.D. dependent var & 0.419719 & \\
\hline Sum squared resid & 0.080123 & & S.E. of regression & 0.085346 & \\
\hline R-squared & 0.967513 & & Adjusted R-squared & 0.958653 & \\
\hline $\mathrm{F}(3,11)$ & $1,091,982$ & & P-value(F) & $1.82 \mathrm{e}-08$ & \\
\hline Log-likelihood & $1,795,773$ & & Akaike criterion & -27.91546 & \\
\hline Schwarz criterion & -25.08326 & & Hannan-Quinn & -27.94563 & \\
\hline rho & -0.445736 & & Durbin's h & -1.814714 & \\
\hline
\end{tabular}

$1 * * *$ statistical significance at $1 \%, * * 5 \%$, and $* 10 \% / 1 * * *$ significancia estadística al $1 \%, * * 5 \%$ y $* 10 \%$.

The result of computation for Weighted Average Cost of Capital (WACC) in Table 2, taken the values from a mature market like the United States of America one and making the necessary adjustment to fit for local conditions in local currency.

Table 2. Weighted Average Cost of Capital (WACC) for the most likely risk scenario, small-industrializer case of palm (Elaeis guineensis) oil. Central America. 2017².

Cuadro 2. Costo Promedio Ponderado del Capital (WACC) para el escenario de riesgo más probable, el caso de un pequeño industrializador de aceite de palma (Elaeis guineensis). América Central. $2017^{1}$.

\begin{tabular}{lccccc}
\hline Parameter & Value & Parameter & Value & Parameter & Value \\
\hline Free risk rate & $3.39 \%$ & Growth rate & $7.00 \%$ & Company risk premium & $6.34 \%$ \\
Unleveared beta & 0.55 & $\mathrm{~W}_{\mathrm{s}}$ & $42.51 \%$ & Country risk premium & $3.46 \%$ \\
Market return & $8.42 \%$ & $\mathrm{~W}_{\mathrm{d}}$ & $57.49 \%$ & WACC (USD) & $\mathbf{1 1 . 3 7 \%} \%$ \\
USA country risk & $5.08 \%$ & $\mathrm{~K}_{\mathrm{d}}(1-\mathrm{t})$ & $10.02 \%$ & WACC (local currency) & $\mathbf{1 3 . 5 5 \%}$ \\
Local country risk & $8.54 \%$ & $\mathrm{~K}_{\mathrm{s}}$ & $13.19 \%$ & Exchange rate & 570.00 \\
Inflation USD & $2.00 \%$ & Debt/Equity & 1.35 & & \\
Inflation local currency & $4.00 \%$ & Leveared beta & 1.26 & & \\
Tax & $4.50 \%$ & Market premium & $5.03 \%$ & & \\
\hline
\end{tabular}

${ }^{1}$ The risk-free rate was calculated as the long-term geometric mean of the Treasury bonds of the United States of America. The unlevered beta was taken based on the average beta for the food industries worldwide. The country risk for both the United States of America and the local risk was taken from the World Bank statistics. From the industry subject of this study, the tax rate applied to profits and the Ws and Wd ratios were taken. The growth rate was taken as an average of the expected growth in sales for the companies in the industry / La tasa libre de riesgo se calculó como una medida geométrica a largo plazo de los bonos del tesoro de Estados Unidos de América. El beta sin apalancamientos se tomó con base en la beta media de las industrias alimentarias de todo el mundo. El riesgo del país tanto para los Estados Unidos de América como para el riesgo local se tomó de las estadísticas del Banco Mundial. De la industria objeto de este estudio, se tomaron la tasa impositiva aplicada a las ganancias y las razones Ws y Wd. La tasa de crecimiento se tomó como un promedio del crecimiento esperado de las ventas de las empresas de la industria. 
The historical parameters of the risk model of the company studied are shown in Table 3, after a process of filtering and elimination of outliers from historical statistics. As for example, the sales whose values present high

Table 3. Risk model parameters for the best probability distribution based on the Akaike (AIC) criteria, small-industrializer case. Central America. 2017.

Cuadro 3. Parámetros del modelo de riesgo para la mejor distribución de probabilidad basada en el criterio de Akaike (AIC), el caso de un pequeño industrializador. América Central. 2017.

\begin{tabular}{|c|c|c|c|c|c|c|c|}
\hline Ratio & Mean & $\begin{array}{l}\text { Standard } \\
\text { deviation }\end{array}$ & $\begin{array}{c}\text { Coefficient } \\
\text { variation }\end{array}$ & Type & Mean $^{1}$ & $\mathbf{A}^{1}$ & $\mathbf{B}^{1}$ \\
\hline Sales growh rate & $13.87 \%$ & $23.70 \%$ & $170.89 \%$ & $\begin{array}{c}\text { Econometric } \\
\text { model }\end{array}$ & Several & Several & Several \\
\hline Gross margin & $21.77 \%$ & $3.26 \%$ & $14.95 \%$ & ExtvalueMin & 0.2176 & 0.2328 & 0.0261 \\
\hline Sales expenses ratio & $1.14 \%$ & $0.36 \%$ & $31.75 \%$ & Extvalue & 0.0114 & 0.0098 & 0.0029 \\
\hline Administration expenses ratio & $14.48 \%$ & $3.19 \%$ & $22.02 \%$ & Normal & 0.1448 & 0.0164 & 0.1211 \\
\hline Short-term investment ratio & $0.24 \%$ & $0.01 \%$ & $4.21 \%$ & Laplace & 0.0024 & 0.0024 & 0.0001 \\
\hline Accounts receivable ratio & $13.22 \%$ & $3.12 \%$ & $23.64 \%$ & Normal & 0.1322 & 0.1322 & 0.0312 \\
\hline Inventory ratio & $5.50 \%$ & $1.05 \%$ & $19.19 \%$ & Laplace & 0.0562 & 0.0562 & 0.0095 \\
\hline Deferred expenses ratio & $0.34 \%$ & $0.11 \%$ & $31.41 \%$ & Uniform & 0.0033 & 0.0014 & 0.0053 \\
\hline Other current assets ratio ${ }^{2}$ & $0.00 \%$ & $0.00 \%$ & $0.00 \%$ & Normal & 0.0000 & 0.0000 & 0.0000 \\
\hline PP\&E growth rate ${ }^{2}$ & $2.26 \%$ & $0.32 \%$ & $14.11 \%$ & Normal & 0.0000 & 0.0000 & 0.0000 \\
\hline Long-term investment rate & $3.49 \%$ & $0.86 \%$ & $24.72 \%$ & Laplace & 0.0349 & 0.0349 & 0.0061 \\
\hline Good will rate ${ }^{2}$ & $0.00 \%$ & $0.00 \%$ & $0.00 \%$ & Normal & 0.0000 & 0.0000 & 0.0000 \\
\hline Biological asset ratio & $5.55 \%$ & $0.91 \%$ & $16.44 \%$ & Pareto & 0.0558 & 6.2525 & 0.0468 \\
\hline Other Assets ratio & $5.07 \%$ & $0.36 \%$ & $7.02 \%$ & Laplace & 0.0496 & 0.0496 & 0.0024 \\
\hline Payable accounts ratio & $14.53 \%$ & $3.60 \%$ & $24.74 \%$ & Uniform & 0.1538 & 0.0984 & 0.2092 \\
\hline Acumulated expenses ratio & $0.61 \%$ & $0.12 \%$ & $20.01 \%$ & Uniform & 0.0059 & 0.0035 & 0.0083 \\
\hline Acumulated taxes payable ratio ${ }^{2}$ & $0.00 \%$ & $0.00 \%$ & $0.00 \%$ & Normal & 0.0000 & 0.0000 & 0.0000 \\
\hline Withholdings payable ratio & $1.07 \%$ & $0.21 \%$ & $20.11 \%$ & Laplace & 0.0103 & 0.0103 & 0.0005 \\
\hline Short-term other liabilities ratio & $0.22 \%$ & $0.10 \%$ & $43.17 \%$ & Uniform & 0.0022 & 0.0004 & 0.0039 \\
\hline Short-term debts ratio & $7.70 \%$ & $1.12 \%$ & $14.58 \%$ & Extvalue & 0.0769 & 0.0723 & 0.0080 \\
\hline Long-term debts ratio & $53.96 \%$ & $7.46 \%$ & $13.82 \%$ & Extvalue & 0.5384 & 0.5076 & 0.0534 \\
\hline Other long-term liabilities ratio & $12.06 \%$ & $3.88 \%$ & $32.16 \%$ & Extvalue & 0.1216 & 0.1035 & 0.0314 \\
\hline Equity ratio & $19.20 \%$ & $3.97 \%$ & $20.69 \%$ & Pareto & 0.1863 & 5.2981 & 0.1511 \\
\hline Surplus ratio & $25.03 \%$ & $4.09 \%$ & $16.36 \%$ & Pareto & 0.2530 & 5.1210 & 0.2036 \\
\hline Reserves ratio & $4.50 \%$ & $0.00 \%$ & $0.00 \%$ & Normal & 0.0450 & 0.0000 & 0.1233 \\
\hline Interest rate on debts & $10.87 \%$ & $4.51 \%$ & $41.49 \%$ & Expon & 0.1049 & 0.0529 & 0.0520 \\
\hline Financial income ratio & $8.73 \%$ & $3.07 \%$ & $35.12 \%$ & Uniform & 0.0892 & 0.0366 & 0.1419 \\
\hline Other expenses ratio ${ }^{2}$ & $0.00 \%$ & $0.00 \%$ & $0.00 \%$ & Normal & 0.0000 & 0.0000 & 0.0000 \\
\hline Other income ratio & $1.05 \%$ & $0.38 \%$ & $36.14 \%$ & Uniform & 0.0107 & 0.0049 & 0.0165 \\
\hline Depreciation ratio & $4.55 \%$ & $1.24 \%$ & $27.30 \%$ & Uniform & 0.0450 & 0.0258 & 0.0641 \\
\hline Amortization ratio & $2.43 \%$ & $0.54 \%$ & $22.24 \%$ & Extvalue & 0.0242 & 0.0221 & 0.0038 \\
\hline Dividend payout ratio & $25.66 \%$ & $5.02 \%$ & $19.56 \%$ & Laplace & 0.2566 & 0.2566 & 0.0368 \\
\hline Tax rate & $34.23 \%$ & $0.00 \%$ & $0.00 \%$ & Normal & 0.0472 & 0.0000 & 0.0000 \\
\hline
\end{tabular}

\footnotetext{
${ }^{1}$ Parameters of better data adjustment to the selected probability distribution / Parámetros de mejor ajuste de los datos a la distribución de probabilidad seleccionada.

${ }^{2}$ Those cases with zero mean did not fit to any probability distribution and value was not a risk parameter / Los casos con media cero no se ajustaron a ninguna distribución de probabilidad y el valor no fue un parámetro de riesgo.
} 
variability (measured by the coefficient of variation of $170.89 \%$ ) led to the decision not to use the historical mean, but instead to use the econometric model of sales adjusted in this study. The last three columns show the statistical parameters obtained according to the best AIC performance criteria.

The business value was close over 40 million dollars (USD) (Table 4), this was lower than investment value measured by means total assets (more than 100 million USD). The company made purchases in immobilized assets between the years 2007 and 2012, which did not have contributed to the operation of the company.

Table 4. Business and equity present value for the company analyzed in a static scenario. Central America. 2017.

Cuadro 4. Valor presente del negocio y del patrimonio para la empresa analizada en un escenario estático. América Central. 2017.

\begin{tabular}{cc}
\hline Item & USD \\
\hline Cash \& cash equivalents & 443,843 \\
Short-term investments & $2,150,394$ \\
Business value & $\mathbf{4 0 , 5 0 9 , 7 3 0}$ \\
Asset value & $43,103,968$ \\
Debt value & $52,557,609$ \\
Equity value & $\mathbf{- 1 2 , 0 4 7 , 8 7 9}$ \\
Investment & $107,211,117$ \\
\hline
\end{tabular}

The present value of the company analyzed and the value of the estimated assets over a period of 10 years, because of the interaction of the parameters analyzed in the previous section (Table 4). The equity value was negative in the horizon studied, given that the degree of indebtedness of the company is higher than the accounting value of the assets over time.

The volatility of the international price generated great sensitivity in operating cash flow and the long debt fixed got the risk high in the value of the equity.

The above is the results on the static scenario without the effect of Monte Carlo simulation. The following provides the results of 1,000 interactions obtained with the Monte Carlo simulation method (Table 5).

In case one (Table 5), the interest rate used for the debt is $10.49 \%$, which was the current average rate of all the debts of the company. The second case represented a new alternative situation faced with a real possibility of adapting long-term debt; it was feasible to think of a scenario where a financial restructuring was presented in such a way that the interest rate is lowered to $6 \%$ per year and assets without production were sold for the sum of $8,771,930^{4}$ USD.

For the case one, the simulation showed that business value oscillates in an average of 42.8 million USD with a standard deviation of 32.7 million USD, and a coefficient of variation of $76.27 \%$ with a probability of negative return of $6.7 \%$, that means, there is expect that every 1,000 scenarios, almost seven of them can be on negative business value. This probability rised extremely at $71.20 \%$ for the equity value because of the weight of the indebtedness in the company. For the equity value, the results have a negative level around 9 million USD with a high risk of $361.94 \%$, measured by coefficient of variation.

In case two, the business value was around 66.2 million USD with a probability of negative return about $4.08 \%$ it showed a best performance, and the equity value was not negative like in case one. The level of risk measured by the probability of negative return falls to $36.5 \%$ from $71.2 \%$ for the case one.

$4 \quad$ Expected value of assets for sale / Valor esperado de los activos para la venta. 
Table 5. Actual situation of the commercial and equity value for the company studied. Central America. 2017.

Cuadro 5. Situación real del valor comercial y capital para la empresa estudiada. América Central. 2017.

\begin{tabular}{lcccc}
\hline \multirow{2}{*}{ Parameters } & \multicolumn{2}{c}{ Case 1 } & \multicolumn{2}{c}{ Case 2 } \\
\cline { 2 - 5 } & Business value (USD) & Equity value (USD) & Business value (USD) & Equity value (USD) \\
\hline Minimum & $-89,868,563$ & $-116,701,933$ & $-64,314,124$ & $-120,906,882$ \\
Maximum & $171,321,142$ & $164,742,174$ & $229,078,456$ & $200,979,883$ \\
Mean & $42,898,655$ & $-9,033,936$ & $66,263,103$ & $13,926,856$ \\
$90 \%$ CI & $\pm 1,703,547$ & $\pm 1,702,340$ & $\pm 2,146,494$ & $\pm 2,176,112$ \\
Mode & $35,639,952$ & $-21,688,529$ & $65,583,607$ & $6,972,046$ \\
Median & $37,912,808$ & $13,857,736$ & $66,684,367$ & $13,279,538$ \\
Std Dev & $32,720,839$ & $32,697,653$ & $41,228,725$ & $41,797,615$ \\
Coefficient of variation & $76.27 \%$ & $-361.94 \%$ & $62.22 \%$ & $300.12 \%$ \\
Probability of negative return & $6.70 \%$ & $71.20 \%$ & $4.08 \%$ & $36.50 \%$ \\
\hline
\end{tabular}

The risk measures improve considerably when the interest rate is lower to $6 \%$ and the sale of assets of little use is allowed.

\section{Discussion}

Overall, as a result, firms that are exposed even to volatile commodity prices may only show a small net exposure if they are hedging effectively with the wide number of hedging products disposables in the market.

While it is true that market price risk hedges are very useful, it is not always possible to cover the entire volatility. For the particular case of crude palm oil prices in Malaysia, Ong et al. (2012) found that the Malaysian futures market only provides a low level of coverage effectiveness $(19 \%-53 \%)$ due to the lower volatility of the CPO spot price.

Commodity prices usually exhibit high volatility and thus represent a priori an important source of risk to nonfinancial corporations and should affect firm value due to their impact on corporate cash flows as input and output factors of the corporate production process (Varangis and Larson, 1996; Bartram, 2005). This could be confirmed in this case study by the high coefficient of variation obtained for the annual sales rate (Table 3), which is derived as a result of the structural econometric model for sales based on the international price, among others variables.

That the international price elasticity of palm oil on annual sales was high (Table 1), and represents that in the event of a $100 \%$ change in price, annual sales are expected to increase by $58.83 \%$. The regression coefficient proved to be significant at $1 \%$.

The company valuation from discounted cash flows carried out in this research has been used in companies dedicated to the production and industrialization of palm oil in Malaysia, where the international price has been correlated with the value of the company in progress and the value appraised by expert evaluators. In this sense, Tan et al. (2018), concluded that the appraisals depend to a large extent on the position of the international price and that at the banking level this type of analysis is very useful for the risk analysis of companies. On the other hand, with a sensitivity analysis for a company in Indonesia, Svatoňová et al. (2015) showed that changes in the net present value of an oil palm plantation were affected to a greater extent by changes in the sale price of fresh 
fruit bunch than changes in the capital costs and recurrent costs. Although it is true that Svatoňová et al. (2015) did not use the same methodology as this study, it was shown how changes in the sale price affect the profitability of a company or a productive project of oil palm.

\section{Conclusions}

Historical data analyzed show that there is a positive correlation between the international price of palm oil and the domestic and international sale price of crude oil and its derivatives. This directly affects the profitability of industrialists mainly because their fixed costs and financial burden represent a significant amount within their cash need. In this case, the study organization made debt-financed investments in non-productive assets and also in productive assets with high recovery periods, when international oil prices were high, without taking steps to cover the risk of a price drop, which generated a negative effect on the value of the estate and on the value of the business.

In the scenarios where different debt conditions were assessed, specifically with a lower interest rate and with the sale of some unproductive assets, there was an improvement in the level of risk and in the values of capital and the business, the above, as a short-term financial improvement strategy in the face of declining revenues.

Such organizations can improve their strategic and financial management over time, when the variables that directly affect the sale price of their industrialized products are analyzed periodically. This analysis is a key element in taking risk prevention policies in the face of the decision to invest in long-term fixed assets through a high level of debt, which can decrease their profitability and ability to generate cash flow.

\section{Cited literature}

Akaike, H. 1974. A new look at the statistical model identification. IEEE 19:716-723. doi:10.1109/TAC.1974.1100705

Allman, K., J. Laurito, and M. Loh. 2011. Financial simulation modeling in Excel: A step by step guide. John Wiley \& Sons Hoboken, NJ, USA.

Baddi, M.H., y J. Castillo. 2009. Distribuciones probabilísticas de uso común. Int. J. Good Consci. 4(1):149-170.

Bartram, S. 2005. The impact of commodity price risk on firm value: An empirical analysis of corporate commodity price exposures. Mult. Fin. J. 9(3-4):161-187.

Benninga, S. 2014. Financial modeling. $4^{\text {th }}$ ed. The MIT Press, London, GBR.

Bilson, J.F.O. 1994. Managing economic exposure to foreign exchange risk: A case study of American Airlines. In: Y. Amihud, and R.M. Levich, editors, Exchange rates and corporate performance. BeardBooks, WA, USA. p. 221-246.

Bonini, C. 1975. Risk evaluation of investment projects. OMEGA 3:735-750. doi:10.1016/0305-0483(75)90075-4

Botond, B., and R. Bela-Gergely. 2016. The use of Monte Carlo simulation in the assessment of an agricultural investment. Forum Econ. Business 19(127):79-112.

Box, G.E., G.M. Jenkins, G.C. Reinsel, and G.M. Ljung. 2016. Time series analysis: Forecasting and control. $5^{\text {th }}$ ed. John Wiley \& Sons, Hoboken, NJ, USA.

Chidambaran, N.K., C.S. Fernando, and P.A. Spindt. 2001. Credit enhancement through financial engineering: Freeport McMoRan's gold-denominated depositary shares. J. Finan. Econ. 60:487-528. doi:10.1016/S0304-405X(01)00051-4

Chinchilla, C. 2008. Muchas caras de las pudriciones del cogollo (y de flechas) en palma aceitera y la importancia de un enfoque integral para su manejo. ASD Oil Palm Papers 32:11-23. 
Correa, T. 2015. Palma aceitera: entre la "flecha seca" y la variación de precios internacionales. INFOCOOP, CRI. http:// infocoop.go.cr/index.php/Palma_aceitera (consultado 26 feb. 2019).

Espejo-Miranda, I., F. Fernández-Palacín, M. López-Sánchez, A. Rodríguez-Chía, A. Sánchez-Navas, y C. Valero-Franco. 2006. Estadística descriptiva y probabilidad. teoría y problemas. 3th ed. Servicio de Publicaciones de la Universidad de Cádiz, Cádiz, ESP.

Fernández, P. 2001. Valoración de empresas. Universidad de Harvard, Cambridge, MA, USA.

González-Cárdenas, A. 2017. La agroindustria de la palma de aceite en América. Rev. Palmas 37(especial):215-228.

Haushalter, G.D. 2000. Financing policy, basis risk and corporate hedging: Evidence from oil and gas producers. J. Finan. 55:107-152. doi:10.1111/0022-1082.00202

Hojjati, S., and N. Noudehi. 2015. The use of Monte Carlo simulation in quantitative risk assessment of IT projects. Int. J. Adv. Network. Appl. 7:2616-2621.

ISTA Mielke GmbH. 2017. Oil world. Palm oil (Malaysia), 5\% bulk: c.i.f. N. W. Europe. Index Mundi. https://www.indexmundi. com/commodities/?commodity=palm-oil\&months=120 (accessed Mar. 5, 2019).

Janeková, J. 2015. Monte Carlo simulation: Risk analysis tool of investment projects. Transfer Inovácií 32:261-263.

Junkes, M.B., A.P. Tereso, and P.S.L.P. Afonso. 2015. The importance of risks assessment in the context of investment project management: a case study. Proc. Computer Sci. 64:902-910. doi:10.1016/j.procs.2015.08.606

Merková, M., J. Drábek, and D. Jelačic. 2013. Application of risk analysis in business investment decision-making. Drvna industrija 64:313-322.

Merková, M., and J. Drábek. 2015. Use of risk analysis in investment measurement and management. Proc. Econ. Finance 34:656-662. doi:10.1016/S2212-5671(15)01682-2

Meza, C. 2012. La "Flecha Seca" de la palma aceitera: aspectos técnicos y estrategias de manejo. Acta Fitosanitaria 51(2):2-4.

Ong, T.S., W.F. Tan, and B.H. Teh. 2012. Hedging effectiveness of crude palm oil futures market in Malaysia. World Appl. Sci. J. 19:556-565. doi:10.5829/idosi.wasj.2012.19.04.1447

Ordoñez, R., y P. Valencia. 2018. Apoyando la palma sostenible en América Latina y el Caribe. PCNPost. https://pcnpost.com/ apoyando-la-palma-sostenible-america-latina-caribe/ (consultado 12 mar. 2018).

Petersen, M.A., and S.R. Thiagarajan. 2000. Risk measurement and hedging: with and without derivatives. Finan. Manag. 29(4):5-30. doi: $10.2307 / 3666367$

Poulter, S. 1998. Monte Carlo simulation in environmental risk assessment--science, policy and legal issues. RISK: Health Safety Environ. 9(1):7-26.

Proctor, K.S. 2010. Building financial models with Microsoft Excel. $2^{\text {nd }}$ ed. John Wiley \& Sons, Hoboken, NJ, USA.

Quevedo, F. 2011. Distribución normal. Medwave 11(5):1-5. doi:10.5867/medwave.2011.05.5033

Sapag, N., y R. Sapag. 2008. Preparación y evaluación de proyectos. 5ta ed. McGraw Hill, Bogotá, COL.

Savvides, S. 1994. Risk analysis in investment appraisal. Project Appraisal 9:3-18. doi:10.1080/02688867.1994.9726923

Simões, D., and L. Scherrer. 2014. Monte Carlo simulation applied to economic and financial analysis of an agribusiness project. Tekhne Logos 5(2):2-14.

Svatoňová, T., D. Herák, and A. Kabutey. 2015. Financial profitability and sensitivity analysis of palm oil plantation in Indonesia. Acta Univers. Agric. Silvic. Mendel. Brunensis 63:1365-1373. doi:10.11118/actaun201563041365 ISSN 2215-3608 doi:10.15517/am.v31i3.40349 
Tan, S.R., H. Ting, N. Lajuni, Y. Yacob, and J.W. Siong. 2018. Evaluating Malaysian palm oil industry using discounted cash flow approach. Int. Res. J. Finan Econ. 167:17-25

Tufano, P. 1996. Who manages risk? An empirical examination of the risk management practices in the gold mining industry. J. Finance 51:1097-1137. doi:10.1111/j.1540-6261.1996.tb04064.x

Varangis, P., and D.F. Larson. 1996. Dealing with commodity price uncertainty. Policy research working paper No. 1167. SSRN. https://papers.ssrn.com/sol3/papers.cfm?abstract_id=620615 (accessed Mar. 28, 2018). 